\title{
Research Paper An economic analysis of area, production of organic products and its export in India
}

\section{R. SATHIYA AND V. BANUMATHY}

See end of the paper for authors' affiliations

Correspondence to :

\section{R. SATHIYA}

Department of Agricultural Economics, Annamalai University Annamalainagar, CHIDAMBARAM (T.N.) INDIA Email : rameshsathiya24@ gmail.com

Paper History :

Received : 19.10.2016;

Revised : 20.01.2017;

Accepted : 30.01 .2017
Abstract : This paper focus on the economic analysis of area, production of organic products and its export in India. India is endowed with various types of naturally available organic form of nutrients in different parts of the country and it helps for organic cultivation of crops substantially. Organic products are grown under a system of agriculture without the use of chemical fertilizers and pesticides with an environmentally and socially responsible approach. India's total area under organic certification is 5.69 million hectares in 2013-14 and its global rank is $10^{\text {th }}$. The growth rate of cultivation of organic area of India is 17.35 per cent; of which wild collection is 10.51 per cent during 2004-2013. Among all the states in India, Uttar Pradesh the has highest area under organic farming followed by Himachal Pradesh, Madhya Pradesh and Maharashtra in 2011-12. The share of export of organic products in terms of volume to USA (42.16 \%) was the highest followed by European Union (32.3 \%), Canada $(21.68 \%)$. The total volume of export of organic products from India was 177765.26 metric tons worth of Rs. 1328.6 crores during the period of 2013-14. Compound growth rate of export quantity of organic products of India is 46.22 per cent and export value is 34.99 per cent during 2002-03 to 2013-14. India exports around 135 organic products; of which, the share of cotton from India was $(54.04 \%)$ followed by cereals and millets (19.79\%) basmati rice (11.00\%) in 2013-14.

Key Words : Organic, Export, Area, Production, Productivity

How To Cite This PAper : Sathiya, R. and Banumathy, V. (2017). An economic analysis of area, production of organic products and its export in India. Internat. Res. J. Agric. Eco. \& Stat., 8 (1) : 75-82, DOI : 10.15740/HAS/ IRJAES/8.1/75-82. 